\title{
Future Challenges in the Steel Industry and Consequences for Rolling Plant Technologies
}

\author{
Bruno Buchmayr ${ }^{1}$, Michael Degner², and Heinz Palkowski ${ }^{3}$ \\ ${ }^{1}$ Chair of Metal Forming, Montanuniversitaet Leoben, Leoben, Austria \\ ${ }^{2} \mathrm{SMS}$ group $\mathrm{GmbH}$, Hilchenbach-Dahlbruch, Germany \\ ${ }^{3}$ Chair of Metal Forming, Clausthal University of Technology, Clausthal-Zellerfeld, Germany
}

Received December 15, 2017; accepted January 14, 2018; published online January 25, 2018

\begin{abstract}
This paper provides an overview of recent steel market developments considering also the global steel oversupply as well as the installed and planned capacity as recessions in some emerging economies. Especially the enormous Chinese investments combined with their actually decreasing demand are a major reason for the deterioration on the steel market. The general steel demand also declines due to slow growth or even reductions in technology fields like ship building, thermal power plants, infrastructural needs, or even the automotive industry. Nevertheless, environmental and energy-efficient production routes are of primary interest, partly handled by thin strip production processes. TMCP (thermo-mechanical controlled processing) remains a main research field for many applications. Increased demands are expected regarding enhanced strength for light-weight design, improved toughness to ensure safety in case of earthquakes and fires, or improved formability to overcome geometrical limits. New steel grades like bainitic steels, nanocrystalline materials, TWIP-steel or grain-oriented electrical sheet metals have led to advanced quality criteria also for rolling plants. Furthermore, steel has to stay competitive against lightweight metals, CFK, and plastics. Some examples of recent innovative processing optimizations are described requiring not only process monitoring but also model-based simulation and real-time online control. Finally, the article states that new holistic strategies are necessary to overcome future challenges.
\end{abstract}

Keywords: Steel market, Thin strip, TMCP, Advanced steel grades, Rolling plants, Process optimization

Univ.-Prof. DI. Dr. B. Buchmayr (ه)

Chair of Metal Forming,

Montanuniversitaet Leoben,

Franz-Josef-Str. 18,

8700 Leoben, Austria

Bruno.Buchmayr@unileoben.ac.at
Zukünftige Herausforderungen in der Stahlindustrie und deren Konsequenzen für die Walzwerkstechnologien

Zusammenfassung: Dieser Beitrag gibt einen Überblick über die aktuellen Entwicklungen am Stahlmarkt sowohl betreffend der globalen Überkapazität als auch der Konjunkturschwächen in den Entwicklungsländern. Die enormen Investitionen und der sinkende Eigenbedarf in China sind Hauptgründe für die angespannte Situation am Stahlmarkt. Der allgemeine Stahlbedarf sinkt durch ein langsameres Wachstum oder sogar durch Rückgänge in den Technologiebereichen wie Schiffsbau, Kraftwerksbau, Infrastrukturentwicklung und auch in der Automobilindustrie. Dennoch stehen die umweltschonenden und energieeffizienten Produktionsrouten, wie bspw. die Dünnbandtechnologie, im Mittelpunkt des Interesses. Das thermo-mechanische Walzen bildet immer noch einen Forschungsschwerpunkt für viele Anwendungen. Verstärkte Nachfragen bestehen in Bezug auf erhöhte Festigkeiten für den Leichtbau, verbessertes Zähigkeitsverhalten im Falle von Erdbeben und Bränden oder Verbesserung der Umformbarkeit zur Darstellung komplexer Geometrien. Neue Stahlgüten wie Bainitische Stähle, nanokristalline Werkstoffe, TWIP-Stähle oder kornorientierte Bleche für Elektromotoren bilden höhere Qualitätsanforderungen für die Walzwerke. Zudem müssen Stähle gegenüber anderen Leichtbauwerkstoffen und verstärkten Kunststoffen wettbewerbsfähig bleiben. Einige Beispiele von innovativen Verbesserungen der Herstellrouten zeigen, dass nicht nur die übliche datenbasierte Prozessüberwachung, sondern viel mehr noch die modellbasierte Simulation und die Echtzeitkontrolle notwendig sind. In Zukunft sind neue holistische Ansätze zur Bewältigung der zukünftigen Anforderungen erforderlich.

Schlüsselwörter: Stahlmarkt, Dünnband, TMB, Moderne Stahlgüten, Walzwerke, Prozessoptimierung 
Fig. 1: Development of crude steel production in the world and in China since 1900

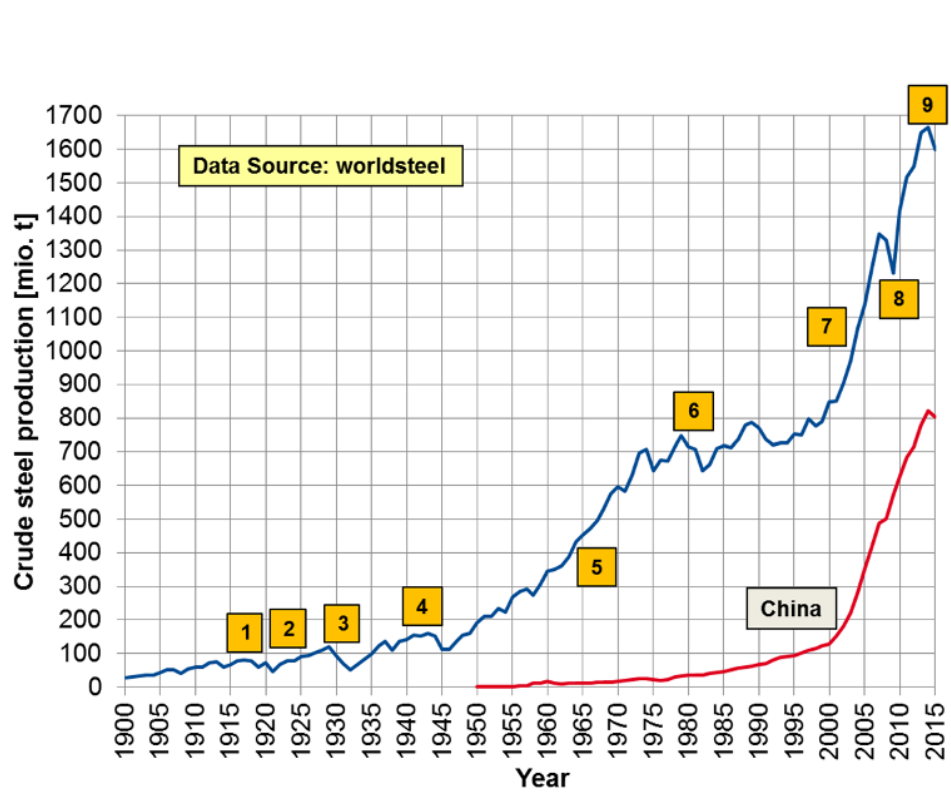

Legend

World War I (1914-1918)

Reconstruction 1919-1929)

The Depression (1929-1934)

World War II (1939-1945)

Reconstruction \& 5 Economic Miracle (1950-1970)

Energy Crisis \&

Local Battles (1970-1995)

Steelboom China (1996-2008)

Financial and

Economic Crisis (2008/2009)

Refugees, Local Battles \& Steel Price Crisis (2015/2016/?)

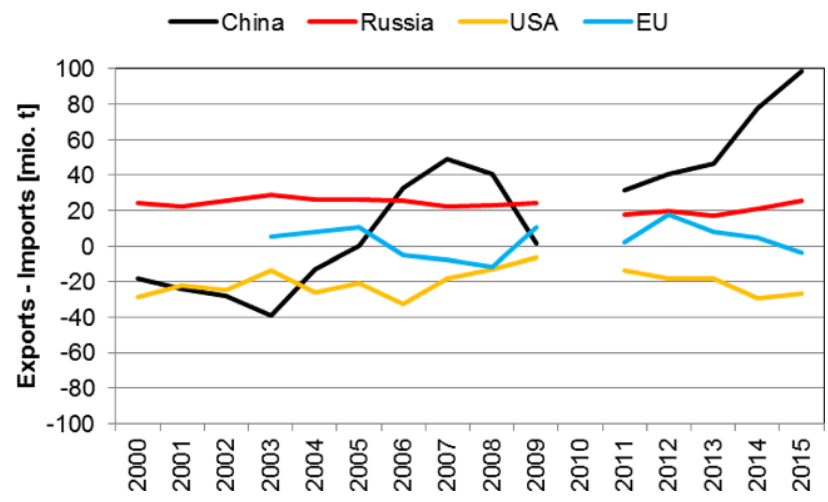

Fig. 2: Exports vs. imports of steel products (Source: www.steel.org)

\section{Introduction}

The current economic situation in the steel producing industry is characterized by a high overcapacity worldwide. One major reason is the overcapacity of steel in China [1], and, in addition, the lower demand of steel in fields like ship building, thermal power plants, infrastructure, and the automotive industry. The development of crude steel production in the world and in China is given in Fig. 1. There are two exceptional growth periods, one after the Second World War and one described as the Chinese steel boom starting in the late nineties. It is evident that the economic opening and the new Chinese policy have also brought an increase of the prosperity [2]. Yet, the higher volume of exports compared to the imports in China, as shown in Fig. 2, has led to some deterioration, which can be seen in Fig. 3, with respect to the development of the steel prices for hot and cold rolled coils in the period between 1998 and 2016. When doing such a market study, some side effects become obvious. They can only be explained by temporal dependencies, such as the event of the Olympic Summer Games
2016 in Brazil, which has dramatically changed the prices for coils, plates, and rebars during the period of the erection of the sport arenas (Fig. 4). The rebar price for concrete buildings doubled during that time.

\section{Technological Developments in Rolling Mills}

Although the rolling technology is quite an old technology, there is always a good reason to improve facilities and machines, either due to new concepts, such as for quality improvements (stability, thickness, tolerances, and more), due to the permanent desire for cost and energy efficiency, or due to IT-technology developments like Industry 4.0. The most important technological steps in the last sixty years are shown in Fig. 5 for hot rolling of flat and long products and in Fig. 6 for cold rolling mills.

Especially the automotive industry has special requirements regarding the surface quality of cold rolled sheet metals. Surface treatments like hot dip or electrolytic galvanizing are commonly used. Some of the recent developments in this field are illustrated in Fig. 7.

\section{Thermomechanically Controlled Process- ing - a Success Story}

About 50 years ago, the first systematic trials were performed to make use of coupled phenomena of recrystallization, phase transformation, and rapid cooling. The physical simulation using "WUMSI" (WarmUMformSImulator at MPI Düsseldorf) or a Gleeble testing machine were indispensable tools at that time to get a deeper understanding of the microstructural processes $[3,4]$. The thermomechanical rolling of structural steels replaced standard CMngrades by fine-grained high strength low alloyed steels 
Fig. 3: Steel price development for hot and cold rolled coils between Jan. 1998 and Sep. 2016

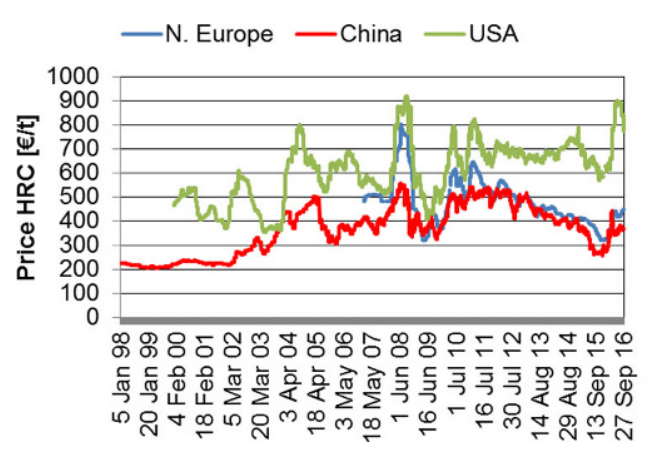

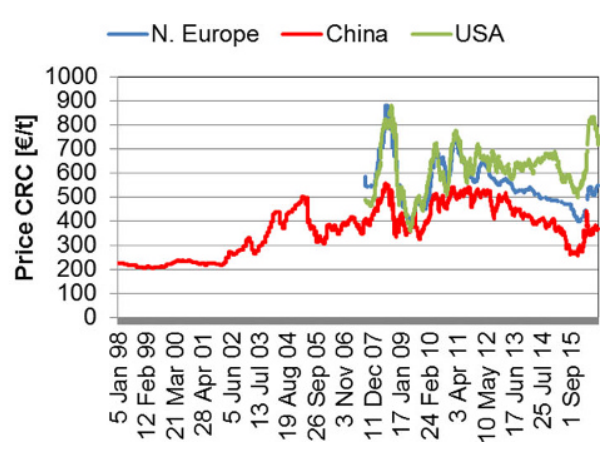
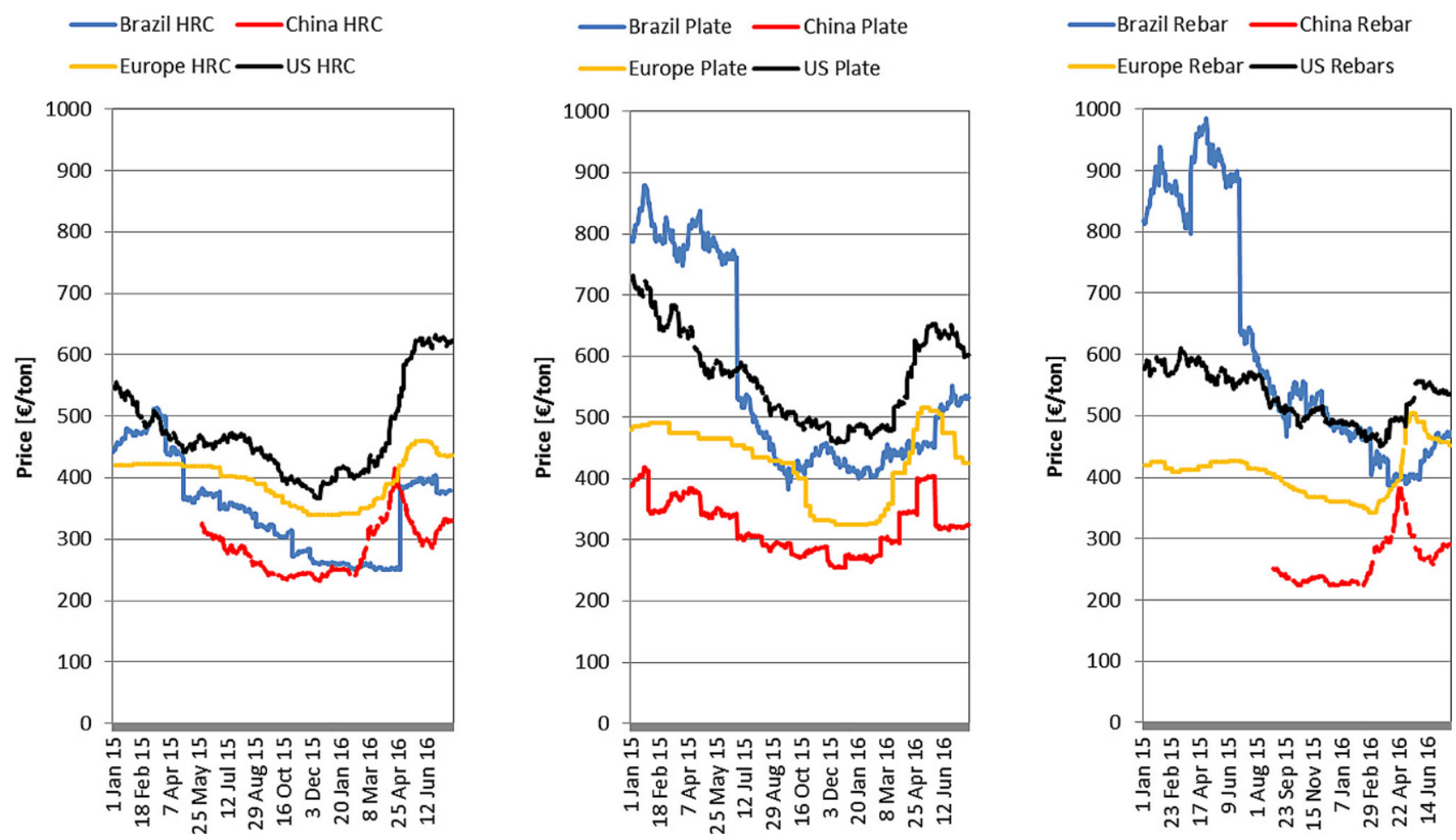

Fig. 4: Steel price development in Brazil during the erection phase for the Olympic Summer Games 2016

(HSLA) characterized by $\mathrm{Ti}, \mathrm{Nb}, \mathrm{V}$-microalloying, and reduced carbon contents [5]. The reasons for low carbon content are the fact that high $\mathrm{C}$ concentrations cause poor weldability and inferior weld toughness [6]. These microalloying elements in combination with TMCP compensate for the strength loss due to a low $C$ content via microstructural refinement, precipitation hardening, and solid solution strengthening as well as strengthening through microstructural modification [7-9].

With these modifications, structural steels have become stronger and tougher with improved weldability and formability having a great impact on the application of structural steel plates and strips [11-13], as for bridges, high-rising buildings, offshore-platforms, pipelines, tanks and containers, penstocks, and more. Pre-rolling, using dynamic recrystallization and finishing rolling at temperature levels closely above $A_{c 3}$, promotes a non-recrystallized austenite condition, which provides a high nucleation density for ferrite formation. These facts result in ferrite grain sizes in the range of some microns [7, 14]. Common concepts for TM rolled HSLA steels are shown in Fig. 8. New cooling strategies have also led to new steel grades, like dual phase (DP), complex phase (CP) steels, and transition induced plasticity (TRIP) steels. High strength low alloy (HSLA) steels have replaced the standard products in many technical areas. The main benefits result from thinner wall thickness-lightweight-and, as a consequence, fewer problems during welding (no preheating to avoid cold cracking, less volume of consumables), and also less effort for transportation. The development of HSLA structural steels is illustrated in Fig. 9. A progress description of high performance steel plates at Nippon Steel \& Sumitomo Metal Corp. is given in [15].

The development of sheet metals for automotive usage has undergone other modifications, like the improvement of the texture to achieve higher r-values for improved deep drawability, starting with the finishing train in the hot strip mill where lubricants are used in the rolling gap to reduce 
Fig. 5: Major technological developments in hot rolling mills for steel
Reinforced \& Superreinforcedlaminar cooling SMS, D

Strip Casting Plant $\left(H^{2} D^{\circledR}\right)$, TU Clausthal \& Salzgitter \& SMS, D

$1^{\text {st }} 3$-strand CSP ${ }^{\circledR}$ plant, Essar Steel India, Hazira, IND

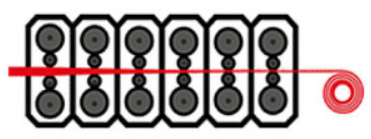

ASC, Trinecke, CZ

TopPlan for HSM \& HPM, IMS, D

$1^{\text {st }}$ Strip Casting Plant, TKN, D

SSP, Thyssen HSM, D

Antipeeling system, Thyssen HSM, D

$1^{\text {st }} \mathrm{CSP}^{\circledR}$ plant, Nucor, USA

ACC cooling system, TM, Dillingen, D)

$1^{\text {st }}$ Coilbox in Europe, HSM Bochum, D

3-roll-techn., bar \& wire rod mills, Kocks, Hilden, D

$1^{\text {st }}$ Coilbox in the world, Westernport, AUS

Hydraulic screw down actuators, HSM Salzgitter, D)

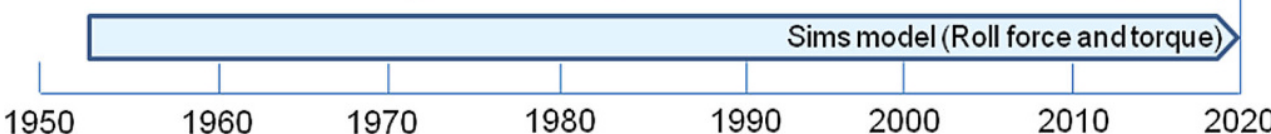

Fig. 6: Major technological development in cold rolling mills for steel

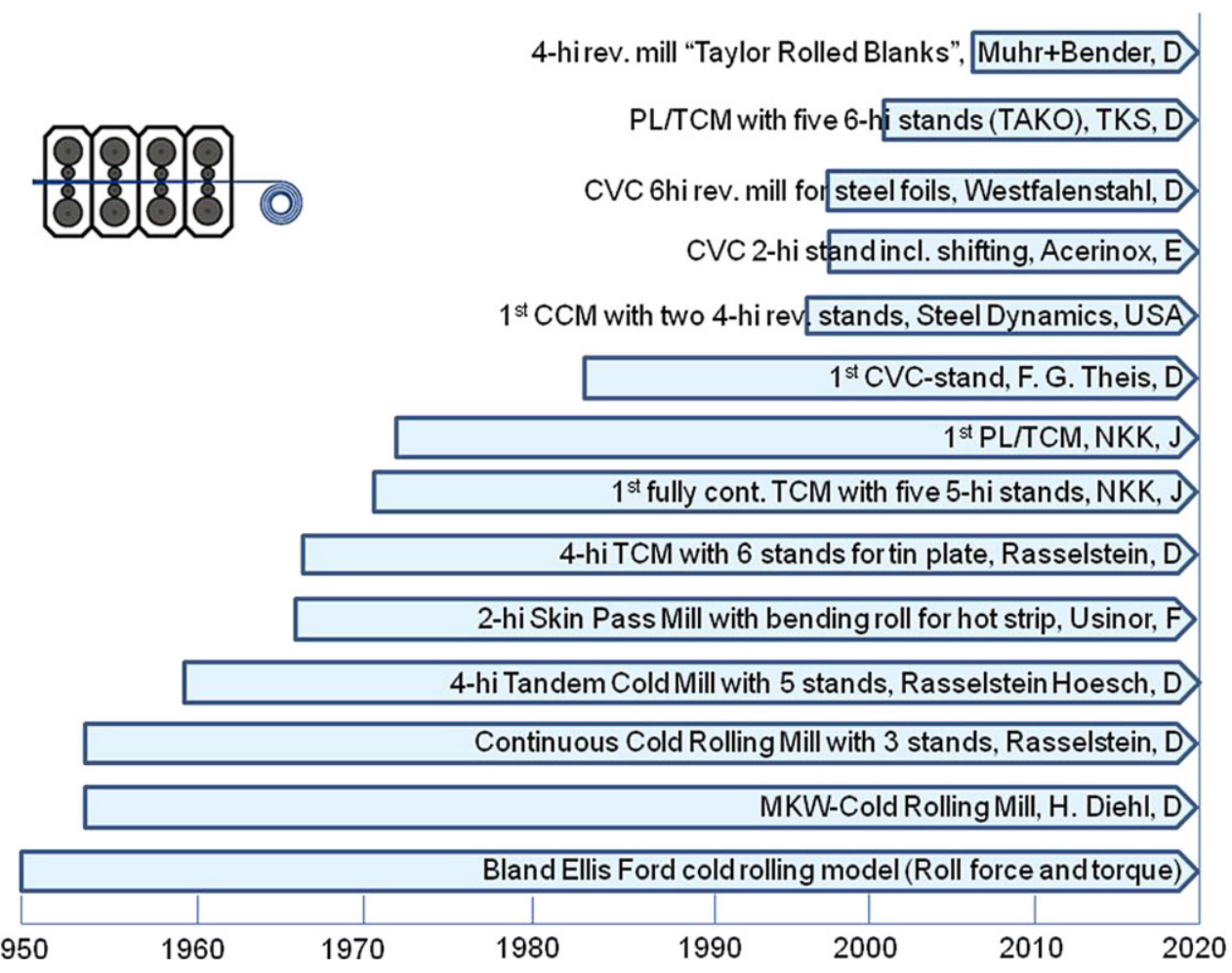




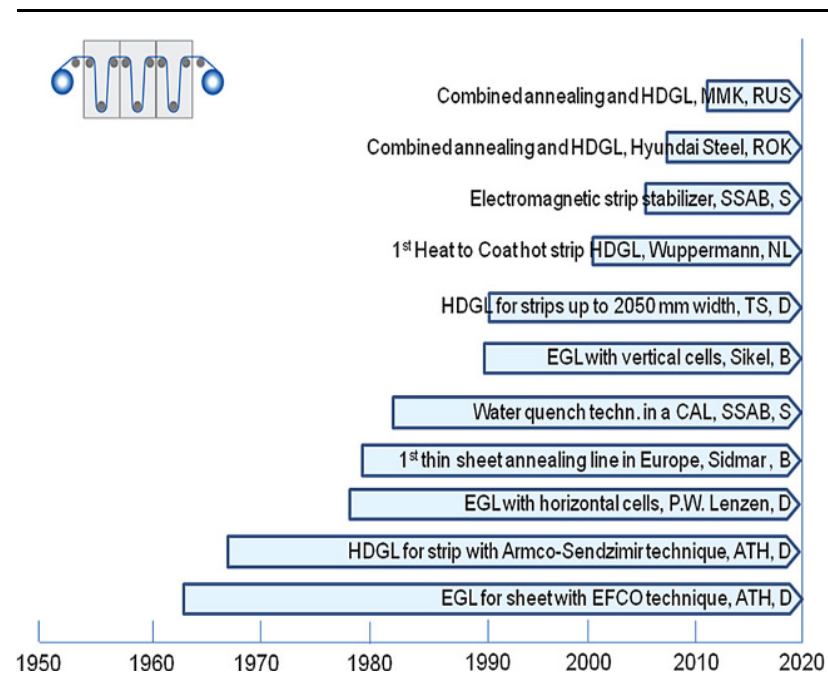

Fig. 7: Developments for galvanizing and annealing lines

friction and therewith shearing of the strip material [16, 17]. TRIP steels were developed for better crash performance. IF steels were produced by Ti-addition and very low C-content for a better deep drawability and special bake hardening $(\mathrm{BH})$ qualities to use the increase of strength by aging during the painting process of the car body. After these changes, the third generation of multiphase AHSS-grades is now of current concern. Steels with high and medium $\mathrm{Mn}$-content show superior ductility values where the effect is mainly caused by the change of deformation mechanisms due to the influence of the stacking fault energy; i.e. twinning replaces slip deformation. Multiphase steels often show a large potential for bake hardening. The increase of strength thus achieved allows a further reduction of sheet thickness and improves the crash safety and the dent resistance. The mechanical strength behavior regarding the $\mathrm{BH}$ effect depends on the microstructure characteristics, type of load path, degree of pre-strain, and bake hardening conditions. $[7,18]$.
Some development steps since 1975 are shown in Fig. 10. The global formability diagram for advanced high-strength steel grades is reprinted in Fig. 11 including traditional low-strength steels for comparison.

\section{New Flexible Cooling Strategies and Cooling Devices}

By a given temperature-time-transformation behavior in previous years, air, air/water-mist, or water quenching were selected to reach proper mechanical properties depending on the plate thickness. Nowadays, the cooling is much more flexible and allows new strategies with new microstructures resulting from that. Quenching and tempering have been replaced by accelerated cooling, direct quenching and self-tempering, quenching and partitioning, rapid cooling and isothermal holding in the bainitic phase field, and many more possibilities $[19,20]$. Residual stresses and distortion have become more important and require special consideration during the processing design. Equipment manufacturers are forced to develop new, more efficient cooling systems, which leads to higher cooling rates or to more flexible cooling procedures. An overview of the most recent developments in Japan in this field is given in Fig. 12. The on-line accelerated cooling device Super-OLAC at JFE uses a unidirectional corridor flow from nozzles located close to the plate. Using this approach, the heat transfer coefficient especially in the film cooling phase can be increased significantly. In the continuous CLC- $\mu$-process, the plate is flattened by a leveler before water cooling in order to achieve a uniform cooling throughout the plate plane. A detailed description is given in [21].
Fig. 8: Microstructure control by TM rolling [10]

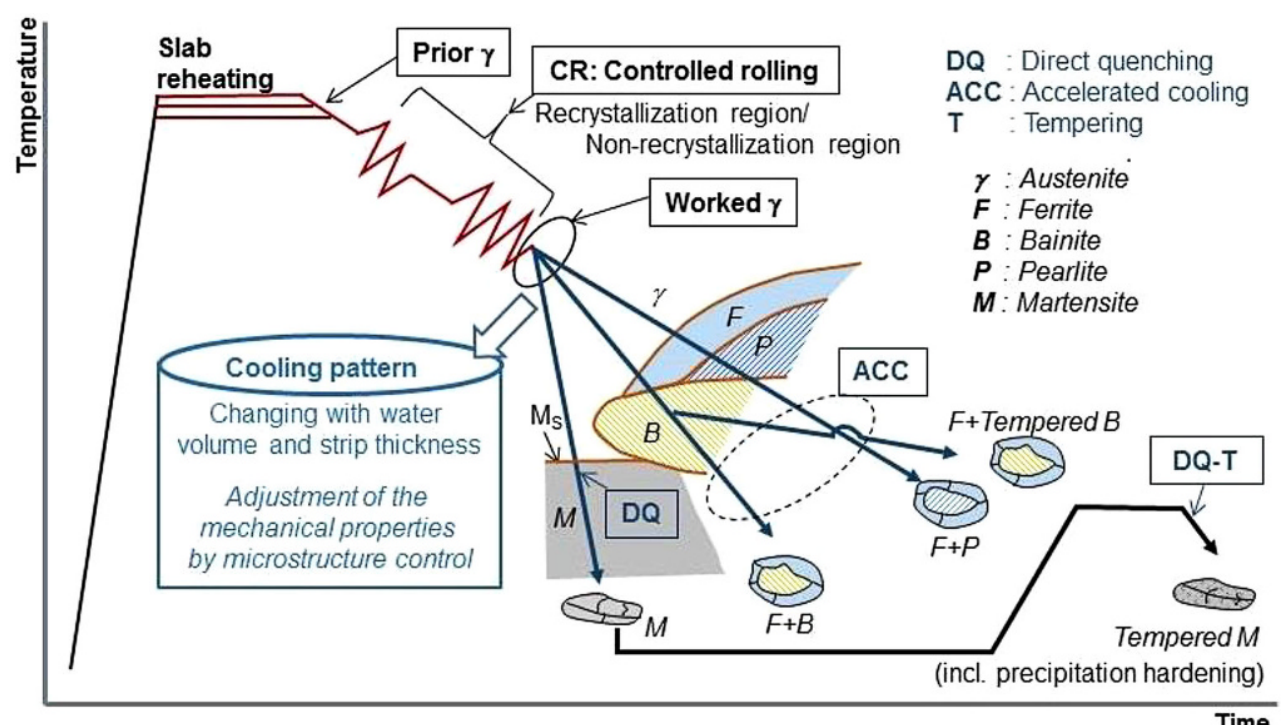

Time 
Fig. 9: Development of high strength structural steels. Source: Stahlinstitut VDEh-WT
Fig. 10: Development of sheet steels for the automotive industry. Source: Institut für Eisenhüttenkunde, RWTH Aachen

\begin{tabular}{l}
\hline N: Normalized rolled or annealed \\
\hline QL: Quenched for low temperatures \\
\hline M: Thermomechanical rolled \\
Quenched
\end{tabular}

S8MNCrNiMo6-6-6
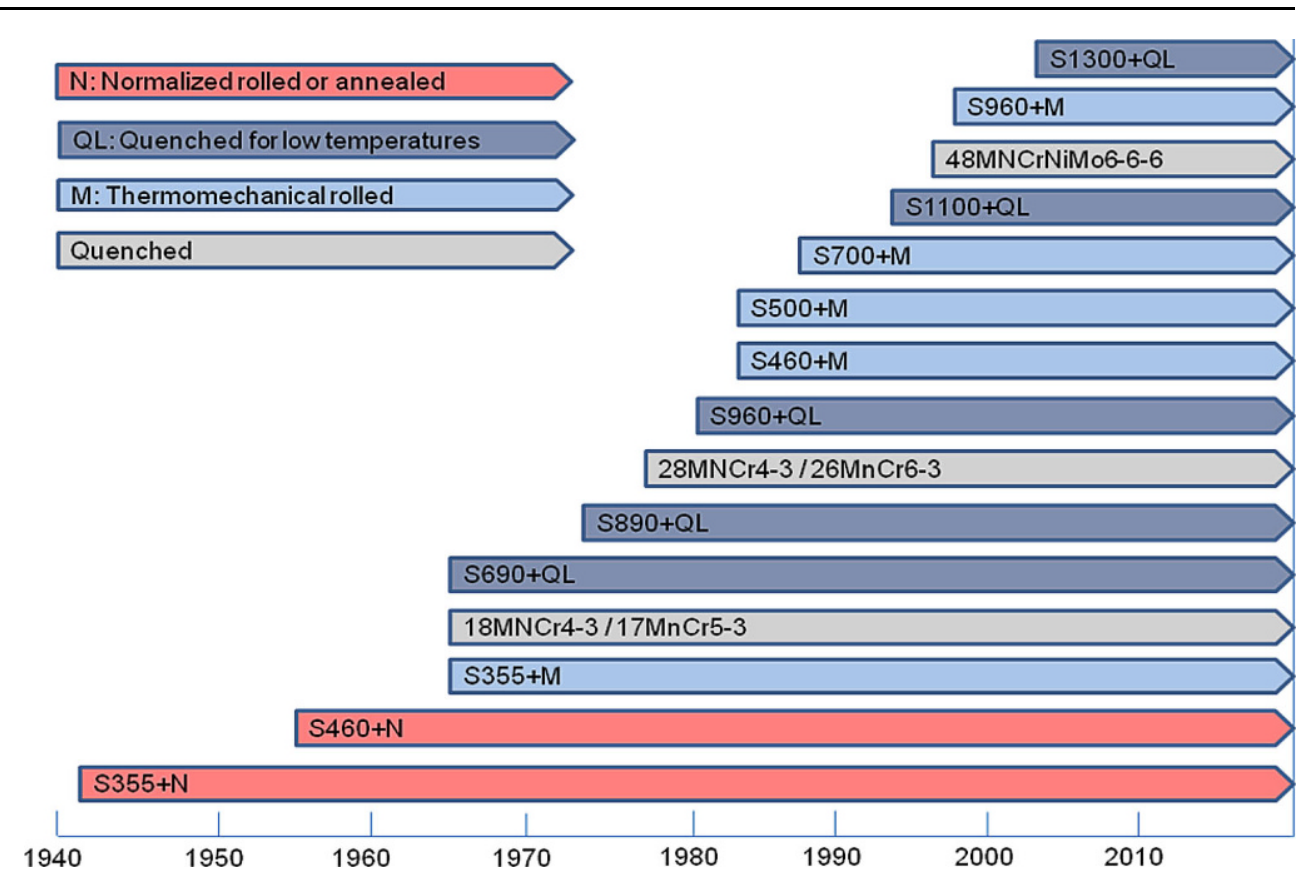

\section{Resource Efficient Production of Steel Strips}

In the early nineties, thin strip casting and direct rolling were the first measures to achieve energy efficient production routes. Under the brand names CSP ${ }^{8}[22]$, ESP [23], and DUE [24], modern alternatives to conventional hot strip mills are still in operation or will be commissioned in the near future. After continuous casting using arc casting machines, a sufficient core reduction is necessary to provide homogeneous microstructures. The finishing rolling is done conventionally and the total percentage of energy use reduction can be up to $75 \%$. Applying this cost efficient technology, sheet metals with a thickness of approximately $1 \mathrm{~mm}$ can be produced. Yet, surface quality finish and duc- tility or deep drawability for some grades are still not comparable with products from standard rolling procedures.

\section{Modelling of Thermomechanical Process- ing and Microstructural Evolution}

The microstructural evolution using TMCP from the reheating furnace to the coiler is nowadays quite well understood and the describing equations for the prediction of temperature distribution, kinetics of static and dynamic recrystallization, precipitations, and phase transformations kinetics have been derived for many steel grades. Instead of a detailed description of the calculation schemes, we advise the reader to look at existing literature [25-31]. Due to the high 
Fig. 11: Formability diagram for today's AHSS grades [17]

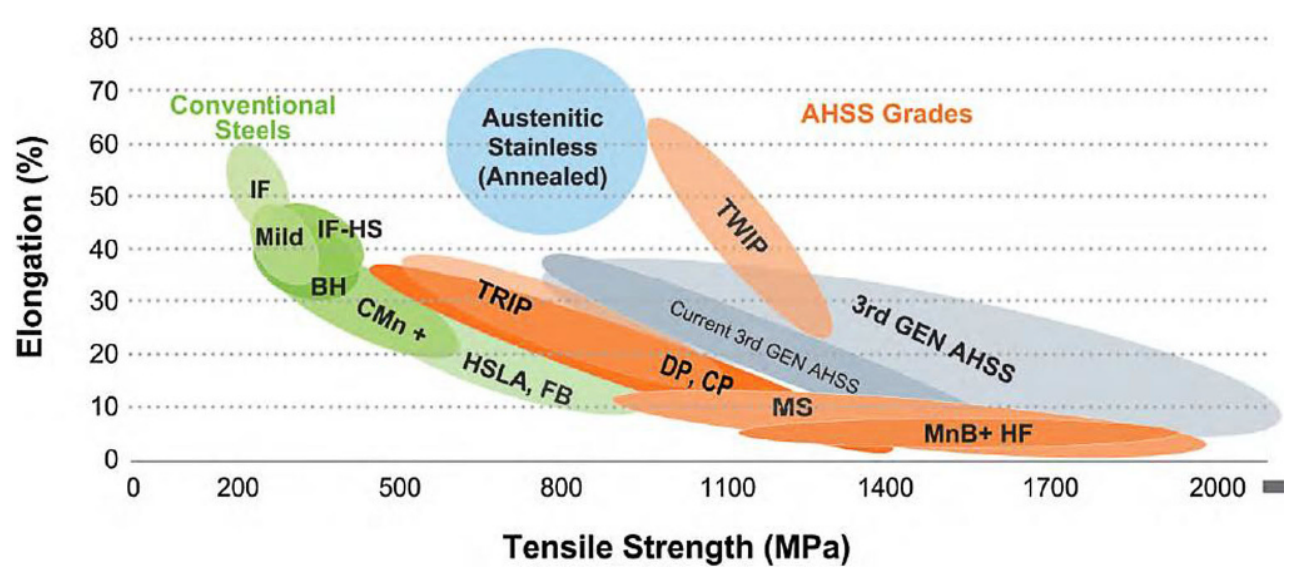

Tensile Strength (MPa)

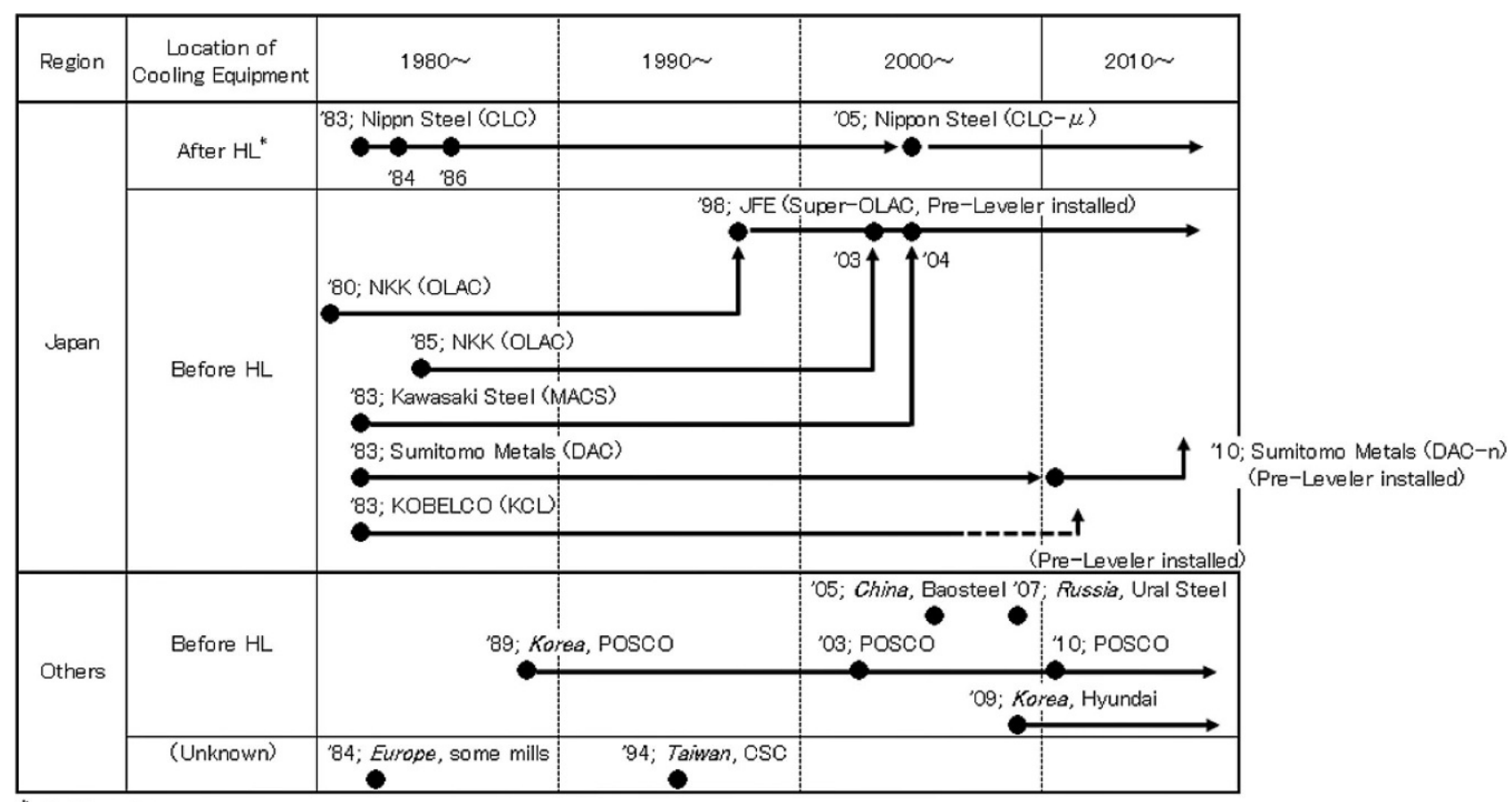

*: Hot Leveler

Fig. 12: Recent developments for versatile cooling at the run-out-table in Japan [19]

rolling speed and short inter-pass times, however, real-time calculations are necessary to allow direct and fast control responses. A recent overview on the closed-loop control of product properties can be found in [32]. In addition, actuators and sensors for hot and cold strip rolling and further processing online monitoring as well as an accurate prediction of flatness and residual stresses are essential to meet future customer requirements.

In cold rolling mills, various optimization techniques are in use to achieve high productivity and quality. An overview of these items and of the availability of robust and accurate models is provided in [33].

\section{Some Thoughts about Future Activities}

Based on the existing microstructural TMCP models, the entire rolling and cooling process can be much better controlled, which leads to narrower tolerances and supports the production of novel steel grades with improved service properties. The rolling mill is replaced by a virtual system, consisting of numerical models for logistic management, thermal management, microstructural control, and more, coupled with accurate sensors. By adding advanced IT-devices and WLAN, the elements of a so-called "Industry 4.0" production unit are already fulfilled. As a consequence of this rapid digitalization, there is a strong need for specially trained personnel and metallurgists, who have not only the metallurgical background but also a sound knowledge of automation and IT-technology. It will be also necessary 
that this new demand finds its way into universities and other education systems.

\section{Conclusions}

The development of advanced steel grades with improved mechanical properties and a better service performance was mainly supported by thermomechanical controlled processing. Nowadays plates and strips are produced with high quality as well as by novel automation and control systems within narrow ranges. Flexible cooling procedures coupled with the use of special alloying concepts have brought new steel grades into the industrial application, like TRIP, TWIP, and medium Mn-steels. Physical and numerical simulations as well as modern characterization devices have become excellent tools which allow a systematic and efficient development of new steel grades. Existing mathematical models will be used to feed advanced control systems, which can be considered equal to Cyber Physical Systems. For future orientation and success, it seems that more creativity or design thinking will be required.

Funding. Open access funding provided by Montanuniversity Leoben.

Open Access This article is distributed under the terms of the Creative Commons Attribution 4.0 International License (http://creativecommons. org/licenses/by/4.0/), which permits unrestricted use, distribution, and reproduction in any medium, provided you give appropriate credit to the original author(s) and the source, provide a link to the Creative Commons license, and indicate if changes were made.

\section{References}

1. Brun, L.: Overcapacity in Steel - China's role in a global problem, Center on Globalization, Governance \& Competitiveness, Duke University, Washington, 2016

2. Buchmayr, B.: Den chinesischen Weg zur Weltmacht verstehen und zukünftige Entwicklungen erkennen, Giesserei Rundschau, 63 (2016), pp 165-168

3. Schmidtmann, E.; Hlawiczka, H.: Wirkung einer thermomechanischen Behandlung auf das Umwandlungsverhalten in der Perlit- und in der Martensitstufe, Archiv Eisenhüttenw., 44 (1973), pp 529-537

4. Kaspar, R.; Streißelberger, A.; Pawelski, O.: Fließspannung im Bereich der $(\gamma \rightarrow \alpha)$-Umwandlung von kohlenstoffarmen Stählen, Archiv Eisenhüttenw., 54 (1983), pp 195-198

5. DeArdo, A. J.; Ratz, G. A.; Wray P. J. (eds.): Thermomechanical Processing of Microalloyed Austenite, TMS-AIME Warrendale, PA, 1982

6. Jeffus, L.: Welding Principles and Applications, 7th ed., Delmar, Clifton Park, USA, 2012

7. Asadi, M.; Soliman, M.; Palkowski, H.: Bake Hardening of Advanced High Strength Steels. In: Totten, G. E.; Colas, R (eds.): Encyclopedia of Iron, Steel, and Their Alloys, London: Taylor \& Francis, 2015

8. Soliman, M.; Palkowski, H.: Influence of hot working parameters on microstructure evolution, tensile behavior and strain aging potential of bainitic pipeline steel, Materials \& Design, 88 (2015), pp 759-773

9. Soliman, M.; Palkowski, H.: Effect of Parameters in the Physical Simulated Rough Rolling Stage on Microstructure Evaluation and Tensile Properties of a Bainitic Pipeline Steel, Materials Science Forum, 854 (2016), pp 3-8

10. Nishioka, K.; Ichikawa, K.: Progress in thermomechanical control of steel plates and their commercialization, Sci. Technol. Adv. Mater., 13 (2012), pp 1-20
11. Streißelberger, A.; Hanus, F.; Schütz, W.; Hubo, R.: Erweiterte Nutzungsmöglichkeiten der thermomechanischen Behandlung von Grobblechen, Stahl und Eisen, 117 (1997), pp. 49-57

12. Hanus, F: Thermomechanisch gewalzte Stähle für den Stahl- und Behälterbau, Seminar Schweißen der thermomechanisch gewalzten Feinkornbaustähle, SLV-Duisburg, Okt. 2000

13. Graf, T.; Thieme, A.; Schröter, F: Moderne Stähle für den Bau von Offshore-Konstruktionen - Herstellverfahren und Eigenschaften, Stahlbau, 83 (2014), pp 10-15

14. Soliman, M.; Palkowski H.: On Factors Affecting the Phase Transformation and Mechanical Properties of Cold-Rolled TransformationInduced-Plasticity-Aided Steel, Metall. Mater. Trans. A, 39 (2008), pp 2513-2527

15. Kojima, A.; Fujioka, M.; Hoshino, M.; Shigesato, G.; Kaneko, M.; Tanaka, M.: Progress of High Performance Steel Plates, Nippon Steel \& Sumitomo Metal Techn. Report, 110 (2015), pp 3-7

16. Degner, M.; Palkowski, H.: Schmierung im Walzspalt bei der Fertigung von Warmbreitband, Der Kalibreur, 63 (2002), pp 53-64

17. Keeler, S.; Kimchi, M. (eds.): Advanced High-Strength Steels - Application Guidelines Version 5.0, WorldAutoSteel, 2014

18. Palkowski, H.; Anke, T.: The Potential of Bake Hardening in Hot Rolled Multiphase Steels. In: Bieler TR (ed.) Trends in Materials and Manufacturing Technologies for Transportation Industries, TMS, Warrendale, PA, 2005, p 101

19. Ouchi, C.: Development of steel plates by intensive use of TMCP and direct quenching processes, ISIJ Int., 41 (2001), pp 542-553

20. Kong, X.; Lan, L.: Optimization of mechanical properties of low carbon bainitic steel using TMCP and accelerated cooling, Proc. Eng., 81 (2014), pp 114-119

21. Endo, S.; Nakata, N.: Development of Thermo-Mechanical Control Process (TMCP) and high performance steel in JFE Steel, JFE Technical Report, 20 (2015), pp 1-7

22. Hoen, K.; Klein, C.; Krämer, S.; Chung, J.-S.: Recent Development of Thin Slab Casting and Rolling Technology in a Challenging Market, BHM 161 (2016), pp 415-420

23. Linzer, B.; Jungbauer, A.; Wersching, G.; Viehböck, A.; Changjiang, Y.; Yao, Y.; Linlei, Q.: The New World of Hot Strip Rolling - Achievments at Rizhao Steels's New ESP Complex Setting New Standards, BHM, 161 (2016), pp 421-428

24. Pigani, A.; Bobig, P.; Knights, M.; Martinis, S.: Danieli Universal Endless (DUE) - The new evolution of Danieli thin slab casting and rolling plant, BHM, 161 (2016), pp 429-439

25. Saito, Y.; Shiga, C.: Computer simulation of microstructural evolution in thermomechanical processing of steel plates, ISIJ Int., 32 (1992), pp 414-422

26. Senuma, T.; Suehiro, M.; Yada, H.: Mathematical models for predicting microstructural evolution and mechanical properties of hot strips, ISIJ Int., 32 (1992), pp 423-432

27. Kern, A.; Degenkolbe, J.; Müsgen, B.; Schriever, U.: Computer modelling for the prediction of microstructure development and mechanical properties of HSLA steel plates, ISIJ Int., 32 (1992), pp 387-394

28. Buchmayr, B.; Samoilov, A.; Lachmann, L.: An offline model for the microstructure evolution of steel plates produced by TMCP, Proc. Conf. Modelling of Metal Rolling Processes 5, The Institute of Materials, London, 1992

29. Buchmayr, B.; Guggenberger, J.; Zuba, G.: Stahlentwicklung mittels Computermodellen - ein Überblick, BHM, 139 (1994), pp 259-266

30. Militzer, M.: Thermomechanical processed steels, in: Comprehensive Materials Processing, 1 (2014), pp 191-216

31. Montmittonnet, P.; Fourment, L.; Ripert, U.; Ngo, Q. T.; Ehrlacher, A.: State of the Art in Rolling Process Modelling, BHM, 161 (2016), pp 396-404

32. Allwood, J. M.; Duncan, S. R.; Cao, J.; Groche, P.; Hirt, G.; Kinsey, B.; Kuboki, T.; Liewald, M.; Stering, A.; Tekkaya, A. E.: CIRP Annals - Manufacturing Technol., 65 (2016), pp 573-596

33. Vaidya, V.A.: Optimization of cold rolling mill process to improve productivity and product quality of steel - an overview, IJEDR, 3 (2015), p 603 